\title{
Chris Marshall
}

\section{RESTORING WHAT?}

\section{The practice, promise and perils of

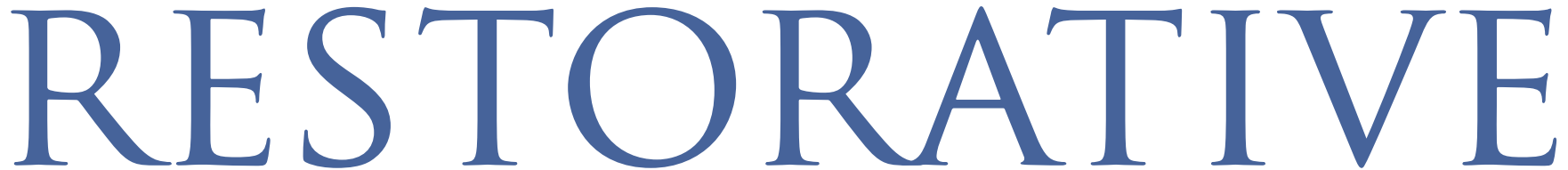

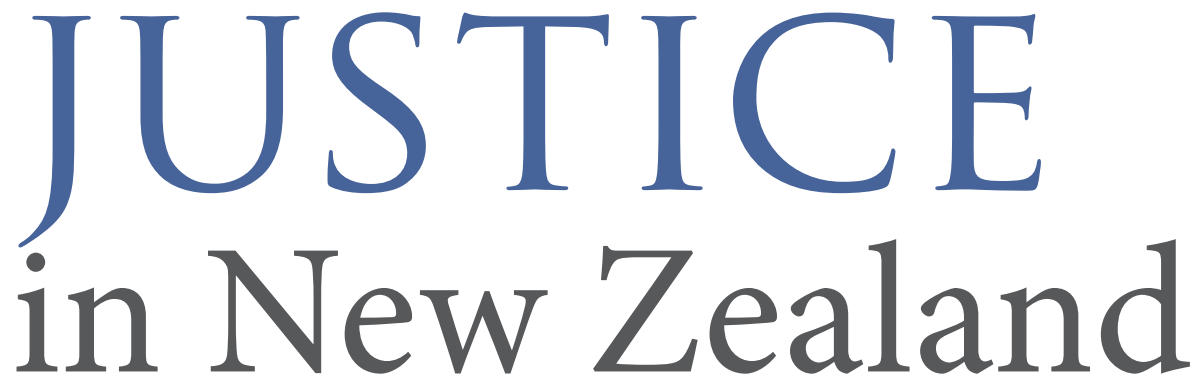

Introduction

In the opening pages of his recent book Crime, Punishment, and Restorative Justice, American author Ross London tells of what prompted him to embark on the journey of discovery that led to the writing of the book. ${ }^{1}$ After more than 25 years of professional involvement in the criminal justice system as an attorney, a public defender and a municipal judge, London found himself asking the question: 'Is this the best we can do?'

Chris Marshall is the inaugural Professor of Restorative Justice in the School of Government at Victoria University of Wellington. Professor Marshall has published widely in the areas of New Testament studies, Christian ethics and restorative justice.
The conventional justice system, he knew, has its merits. Evolving over centuries, it has proved reasonably effective in keeping crime under tolerable levels of control, while at the same time giving place to an ever-expanding body of basic human rights. Yet, reflecting on personal experience London was left, even on his better days, with a hollow feeling inside, a feeling that the system was not actually achieving much good at all.

Despite the efforts of many brilliant minds and the expenditure of vast sums, we have managed to create a criminal justice system that transforms innumerable personal misfortunes into yet other calamities. Victims, who have suffered the trauma of crime, enter the portals of this system with high expectations of justice, only to find themselves wandering its halls feeling bewildered, unfulfilled, and used. For those accused of a crime, 
entry into the system portends the beginning of a personal nightmare of dehumanization, ruinous financial losses, and unending suspicion ... As a criminal justice professional, I came in contact with hundreds of human beings caught up in this labyrinth. Time and again, I saw the same look of despair on those who emerged from the process, embittered, exhausted, and defeated. (London, 2011, p.1)

Pondering this dismal state of affairs, London decided that the American criminal justice system is 'fundamentally flawed'. The problem is not with the people who administer the system. Judges, he notes, with precious few exceptions are no fools. The problem is break the cycle of crime, blame, and punishment. (ibid., pp.2-3)

Searching for answers, London took himself back to graduate school to study criminology. Criminologists, he found, had lots of interesting things to say about crime, but shared little agreement on its causes or on how best to reduce it. Detached from the real world of legal practice, they proposed theories of punishment that bore no relation to 'the reality of sentencing practice I had seen in every courtroom I had ever entered' (p.5). He also found that, as a breed, criminologists tended to be even more cynical and confrontational than are the most hardened trial attorneys.

But some good did come of his induction into criminology: he

\section{... a good case can be made for commencing the modern restorative justice story [is] Canada in 1974, where a Mennonite probation officer, Mark Yantze, and a volunteer prison worker, Dave Worth, ... took two young men ... to meet their victims to discuss reparation and to offer to do community work.}

with the adversarial nature of the system itself, with its 'winner takes all' approach to litigation in which success for one side invariably means defeat for the other, and a defeat of sometimes crushing proportions.

It seemed to me that, in devoting all of its efforts to the tasks of determining culpability and imposing sanctions, the criminal justice system had succeeded in becoming an efficient instrument for condemnation and exclusion, but had utterly failed as an instrument of healing and reconciliation. The system that had evolved as a powerful instrument for apprehending criminals, assessing blame, and imposing punishment was oddly indifferent to the need of the victim, the offender, and the community to encountered the work of Howard Zehr and John Braithwaite and their 'beguiling' notion of restorative justice. Immersing himself in their writings, and of others in the so-called restorative justice movement - which he characterises as 'a veritable "Noah's ark" of criminal justice critics, idealists, and reformers" ${ }^{2}$ - London concluded that 'the original visionaries of restorative justice have bequeathed to the world a wonderful gift: an idea to transform criminal justice as we know it' (pp.6, 269). It is an idea that has 'engaged the energies and excited the hopes of criminal justice reformers throughout the world over the last several decades', and will continue to do so (p.315). But it is also an idea, London says, whose potential remains seriously under-realised - partly because of the ideological blind spots and romantic illusions of some of its proponents, and partly because restorative theorists are yet to adequately bridge the gap between informal justice (that is, the private justice of personal encounters between individuals in conflict) and formal justice (the demands of the public justice system, which must operate in the interests of society as a whole) (p.20, cf. pp.41-56, 161-206). Until it finds a way to reconcile these two domains, restorative justice risks remaining on the sidelines of the criminal justice system, doomed ultimately to irrelevance and marginality.

To help overcome this dilemma, London offers his own recipe for how restorative justice can move 'from the margins to the mainstream'. Some of his proposals are peculiar to the American system, and there are features of his analysis with which I would take issue. But in building his case London introduces one fresh, overarching concept to the debate that I have found particularly helpful, and to which I will return in due course. First, however, let me locate the debate in a broader historical context.

\section{Emergence of restorative justice}

The whakapapa of the restorative justice movement is complex and disputed, with different scholars tracing its emergence to different influences. This is hardly surprising. Social reform movements nearly always have fibrous root systems rather than a single taproot: they are shaped by a wide array of historical forces and draw sustenance from a diversity of sources. Nonetheless, a good case can be made for commencing the modern restorative justice story in Canada in 1974, where a Mennonite probation officer, Mark Yantze, and a volunteer prison worker, Dave Worth, with permission from the sentencing judge took two young men who had vandalised 22 properties in their small town to meet their victims to discuss reparation and to offer to do community work. After the meetings, the judge ordered the youths to pay restitution to the victims as a condition of probation.

That experience led to the birth of the first 'victim offender reconciliation program' - or VORP - which was established in Kitchener, Ontario in 1976, and two years later in Elkhart, Indiana. As the name suggests, the aim of VORP was 
to bring victims and offenders together, with a mediator, to talk about the wrong that had been done and to discuss how it could be repaired, thus hopefully paving the way for reconciliation to occur. Intellectual capital for this new approach, which was soon being replicated elsewhere in America, came principally from the work of criminal justice historian Howard Zehr. In the training manuals, promotional materials and other literature Zehr produced, a new way of thinking and talking about the problem of crime and the requirements of justice began to take shape, though it was not initially called 'restorative justice'.

The programme flourished over the next 15 years, and began to attract international attention, especially after the publication of Zehr's influential 1990 book Changing Lenses: a new focus for crime and justice. In 1994 the victimoffender mediation process was endorsed by the American Bar Association, and the following year by the National Association for Victim Assistance. By the end of the 1990s the idea of restorative justice had become familiar to criminal justice reformers and scholars all around the world, and it is today considered one of the most fertile fields of criminological thought. It has been called one of the 'big ideas' in contemporary justice studies, and even the most significant innovation in the administration of justice since the emergence of the nation state (see Marshall, 2012, pp.4-7, 301-3; also Johnstone, 2012, pp.1-8, 133-59).

What began, then, as a trickle near Toronto has since become a torrent. There are over 400 victim-offender mediation schemes in the United States alone, and a comparable number in Europe. It is estimated that similar programmes now exist in over 100 countries, with more and more governments showing interest in the potential of restorative justice to curtail crime and reduce its costs to society. Significant multinational bodies, such as the United Nations, the Council of Europe and the European Union, have issued conventions calling on member states to develop restorative options and specifying standards of good practice. Academic engagement with the subject has also exploded. There are now hundreds of scholars working in the field, dozens of conferences held every year, and mountains of secondary literature that grow higher by the day.

The speed with which all this has happened is quite extraordinary. Clearly there is something about the idea of reframing or reimagining the criminal justice problem in relational and reparative terms, rather than in solely legal and retributive terms, that has resonated with people all around the globe. The reason it has done so, I suspect, is that the notion of restorative justice signals that justice is about concrete change. It is not just about abstract principles, or legal doctrines, or human rights, or metaphysical beliefs; it is about changing things on the ground. True justice restores what has been lost; transgressions and needs of their young people. It was not, as is sometimes claimed, a conscious attempt to recover Māori customary practices for dealing with family or tribal conflict; rather it was a bureaucratic endeavour to provide a simpler, more flexible, and culturally more appropriate way of processing young offenders.

It was also not a conscious attempt to introduce restorative justice philosophy into the mainstream system. The working party that crafted the legislation had no awareness of restorative justice theory as it was emerging overseas. It was only after Youth Court judge Fred McElrea encountered Howard Zehr's work during a period of sabbatical leave in England in 1993 that FGCs began to be hailed as an

\section{... [a New Zealand] Youth Court judge Fred McElrea encountered Howard Zehr's work ... in 1993 that FGCs began to be hailed as an internationally unique example of state-sponsored restorative justice, and on a colossal scale.}

it rectifies or repairs what has been broken; it transforms people's lived experience. That way of conceiving of justice intuitively makes sense to people, even if they do not know how to define it, or describe it, or achieve it in practice.

\section{New Zealand's chapter in the story}

Within this larger narrative of origins Aotearoa New Zealand has its own chapter to tell. This, too, is a complex and perhaps disputed story, which there is no space to lay out in detail here. But two key 'moments' are worth noting. The first was the passing in 1989 of the Children, Young Persons and Their Families Act, which mandated the use of so-called 'family group conferences' - or FGCs - for all young offenders (except those guilty of murder or manslaughter). This was an entirely new mechanism, intended to, among other things, recognise the rights of children, honour Treaty of Waitangi obligations, and allow families to take leadership in dealing with the internationally unique example of statesponsored restorative justice, and on a colossal scale. Whether that is true or not depends on how strictly one defines restorative justice. But there can be little doubt that the participatory, whānaubased format of the FGCs was well suited to producing restorative outcomes, and the impact of the new system in reducing incarceration rates of young people was dramatic. Many other countries have since followed New Zealand's lead in this innovation, and we are still regarded internationally, rightly or wrongly, as something of a mecca for good youth justice policy (MacRae and Zehr, 2004; Lynch, 2012).

The second key moment in the New Zealand story was in 1994 when Judge McElrea invited the Reverend Douglas Mansill, a Presbyterian minister in Auckland, to facilitate the first adult restorative justice conference, based on the FGC precedent. Other conferences soon followed, and within the space 
of a few years community groups of voluntary facilitators, beginning with $\mathrm{Te}$ Oritenga in Auckland, had sprung up all over the country, offering restorative justice services to their local courts, with the support of sympathetic judges. This remarkable groundswell of communitybased activism, together with the backing of key political and judicial figures, led to a four-year-long court-referred pilot scheme trialling the use of restorative justice conferencing for adult offenders in four district courts (2001-04). It also enabled the incorporation of the first explicit reference to restorative justice in four key pieces of legislation: the Sentencing Act 2002, the Parole Act 2002, the Victims' Rights Acts 2002 and the Corrections Act 2004. Over the ten years the ever-widening range of application of restorative justice principles and practices, which creates significant problems for defining the field and distinguishing its normative features. The question 'What is restorative justice?' is actually becoming harder, not easier, to answer as time passes. The second trend is the mounting interest governments are taking in restorative justice, which raises the knotty issue of how restorative justice can be integrated into the mainstream system of social control and punishment without compromising its ideals or blunting its radical edge. Both these trends are widely discussed in the academic literature, and in the practitioner community, so let me say something more about each.

\section{Some theorists place predominant emphasis on the noun 'justice', and limit restorative justice to a particular way of pursuing justice after the occurrence of a crime, one which focuses on a respectful, facilitated encounter between victim and offender.}

since, government has continued to fund the provision of adult restorative justice services through community providers at a fairly modest level. But there has been a notable increase in commitment over the past couple of years, including Ministry of Justice support for moving boldly into the two most challenging areas of practice (both excluded from the pilot): those of sexual offending and family violence.

A great deal more could be said about the current restorative justice scene in New Zealand. There are some facets that are unique to us, especially with respect to the Treaty context which frames how we must wrestle with justice issues in this society. But most of what is happening in New Zealand is characteristic of 'second wave' trends in restorative justice internationally.

Two of these trends are worth highlighting, because both raise fundamental issues of principle. The first is

\section{An expanded field of application}

Perhaps the most striking development over recent decades has been the substantial increase in the range of application of restorative justice principles and procedures, both within the criminal justice system and beyond it. Within the system, restorative justice has always been predominantly used for young offenders and for offences of a relatively minor nature. This is partly because it has been much easier to commend restorative priorities to politicians and policy makers in this space, in view of the long-standing belief that youngsters who offend, because of their immaturity, require interventions of care and support, not merely of punishment. But, while remaining most firmly rooted in the youth jurisdiction, there has been a progressive expansion of restorative justice into the adult domain as well, and with respect to crimes of the most serious nature.
In fact, contrary to what most people assume, research confirms what practitioners know to be true from experience: namely, that restorative justice is most effective when the crime is most serious. The greater the trauma involved, the more powerful restorative approaches can be (Strang and Sherman, 2007$, pp. $21,37,68,70,75)$. Indeed, in the most recent survey of research, published in November 2013, the authors conclude that 'there can be high confidence of good results with violent crime, and somewhat less confidence with property crime', so that the common strategy of 'banishing restorative justice conferences to low-seriousness crimes is a wasted opportunity. If governments wish to fund restorative justice at all, this evidence suggests the best return on investment will be with violent crimes, and also with offenders convicted after long prior histories of convictions' (Strang et al., 2013, p.48; also Joudo Larsen, 2014, pp.vii, 10, 23, 32, 33).

As well as an expanded reach within the justice system, there has also been a remarkable outward 'migration' of restorative practices into other spheres of social life, where they have been used to address more everyday problems: disruptive behaviour in schools, antisocial activities in the community, interpersonal conflicts and employment grievances in the workplace, incidents of abuse in residential and daycare facilities, misconduct in sports teams, disputes between neighbours and communitylevel conflicts, disciplinary procedures in the armed forces, student misconduct in higher education, and complaints against corporate bodies for non-compliance with regulatory schemes. The application to schools has been particularly impressive and inspirational. There has also been a migration 'upwards' from the domestic sphere to the sociopolitical sphere, where restorative practices have been used to deal with episodes of political violence, gross violations of human rights, hate crimes, ethnic conflict and genocide, and the destructive legacy of historical wrongs, such as slavery, racial discrimination and colonial land confiscations.

Each of these new spheres of application has unique challenges. But 
in every case the concept of a justice that remediates, not merely retaliates has provided a constructive new lens for viewing the issues at stake and for developing a range of distinctive processes to address them.

\section{Problems of definition}

But distinctive in what way? What qualifies some practice or procedure or perspective as restorative justice? How should the term be defined and what limits should apply to its application? There has never been full agreement on this issue, and it has become more contentious than ever. ${ }^{3}$ Some theorists place predominant emphasis on the noun 'justice', and limit restorative justice to a particular way of pursuing justice after the occurrence of a crime, one which focuses on a respectful, facilitated encounter between victim and offender. Others give more force to the adjective 'restorative' and broaden the designation to include any approach to human conflict that promotes collaborative decision-making and peacebuilding in place of antagonism, coercion and exclusion. Some widen it even further to embrace a whole way of viewing the world and living within it 'restoratively', in every department of life. ${ }^{4}$

Rather than choosing between these options, or abandoning the label as now so inclusive as to be meaningless, it is better to envisage a continuum between minimalist and maximalist conceptions of restorative justice. The spectrum ranges from those who restrict the category to a particular criminological procedure, at one pole, to those who apply it to an entire way of life at the other, with applications to personal, political and professional conflicts falling at points in between (Johnstone, 2012, p.157). Within each application there is also a continuum between interventions that are minimally restorative and those that are maximally restorative. Practice models, for example, which work solely with one party to an offence - be it the victim, offender, or those secondarily caught in the slipstream - will only be partially restorative in effect, whereas models that enable all the parties involved to collaborate on devising a mutually beneficial solution have the potential to be maximally restorative (Zehr, 2002, pp.54-7).
For all its fluidity and multiplicity of uses, there remains something recognisably distinctive about a restorative framework for approaching personal and social harms, something that marks it out as different from business as usual; something that sets it apart from both retributive and rehabilitative approaches that have long dominated the penal landscape. Restorative justice shares with retributivism a concern to rectify the imbalances created by crime in a morally serious manner, and it resembles utilitarianism in its rejection of avoidable suffering in the quest for resolution. Where it departs from both, however, is in the thoroughgoing 'relationalism' of its undergirding concepts of justice and
To speak of crime as injury is not mere emotionalism; it is how victims actually experience crime and other injustices. Victims usually know themselves to be victims because they feel violated, not because they realise some legal rule has been broken. It is the very pain of such violation, and the visceral resentment it always triggers, that helps us to locate the presence of an injustice. Philosophers may not be able to agree on how to define 'justice', but they can usually agree on where injustice has occurred. Injustice manifests its presence as intentional injury to the innocent and as a contemptuous disrespect of their rights. That, essentially, is what crime is too.

This leads to the second distinguishing

\section{... [Annalise Acorn] notes, justice does not reside in any second-order tokens, such as retributive punishment, nor in any of the procedural steps in the restorative process, such as personal encounter, confession, restitution or forgiveness.}

justice making. The distinctiveness of these concepts is easiest to describe in criminal justice terms, but the analysis can be extended by analogy to other domains as well.

\section{Three core convictions}

Restorative justice practice is informed or controlled by three core convictions or foundational assumptions. The first is an understanding of crime as injury more than infraction. Crime is not viewed simply as the breaking of the law, or the transgressing of some moral or spiritual code; it is the harming of actual persons, the infliction of real personal losses, the tearing of the web of relationships that interconnect us in society: the wounding, indeed, of our very humanity. Not all harms are crimes, of course, and not all crimes cause equal harm. But what fundamentally marks out crime as wrong is that it injures, or seriously threatens to injure, the persons involved and violates their relational integrity. feature of restorative philosophy: its notion of justice as the existence of right-relations between persons. The injury done through criminal or other intentional wrongdoing is fundamentally a relational injury. It is the dishonouring of the kind of relationship that ought exist between the parties as fellow citizens and fellow human beings. In her searing critique of restorative justice, Canadian legal scholar Annalise Acorn identifies this as the key idea that sets restorative justice apart from other theories of justice - its notion of justice as rightrelation and crime as wrong-relation. For restorativists, she notes, justice does not reside in any second-order tokens, such as retributive punishment, nor in any of the procedural steps in the restorative process, such as personal encounter, confession, restitution or forgiveness. It inheres rather in the establishment of a right-relationship between the parties. 'The justice to be restored is the experience of relationships of mutuality, equality, and respect in community. And 
it is this extravagant ambition - this understanding of justice in terms of an idealised conception of right-relation that is the single distinguishing element of restorative justice' (Acorn, 2004, p.22).

Acorn goes on to object strongly to such a conception of justice because it sets the bar impossibly high. It requires of victims a supererogatory devotion to forgiveness and reconciliation, while denying them their right to seek a total disconnection from their abuser - which is what victims of sexual or domestic violence, in particular, often want and require. 'They don't want right-relation', Acorn exclaims. 'They want no relation. And they want to be able to look to a powerful and trustworthy state capable of prohibiting relation' (p.116).

But Acorn misses the point. To speak at their relational core (including their relationship to themselves), and distorts the rightful conditions that bind them together in community, then justice must require the repairing or healing of the injury. This is something the punitive justice system largely fails to deliver, because punishment does little or nothing to heal, either the offender or the victim. Long ago, George Bernard Shaw put his finger on the problem of punishment for offenders: 'If you are to punish a man retributively, you must injure him. If you are to reform him, you must improve him. And men are not improved by injuries' (Shaw, 1961, p.26).

The problem for victims is even greater. A system that devotes almost all its energies and resources to punishing offenders has little left over for victims. It

\section{... a meeting where the story of the damage done through the collision of their lives in the wrongful event is told as truthfully and fully and compassionately as possible, and where all those directly affected together decide what is needed to write a new chapter ...}

of justice in the wake of crime as the recovery of right-relations is not to imply the emergence of a new-found intimacy and mutuality between the parties. It is to suggest, rather, the restoration of rightness to their relationship. The relationship is righted or rectified or 'right-wised' because the wrongs that have blighted it have been exposed and dealt with, not because new depths of intimacy and respect have arisen. It is therefore a healthier relationship than it was before and, in that sense, a 'right' relationship. But it is not necessarily a closer or ongoing relationship, which may not be the right kind of relationship for the parties to have anyway (see further Marshall, 2012, pp.302-12).

This brings us, then, to a third distinctive theme in restorative justice philosophy: its understanding of justicemaking as repair. If crime injures persons may be true in some cases that knowing that the person who wronged them is being punished may help a victim's emotional recovery (more research is needed on this question: see London, 2011, pp.98-103). But it will only ever be of limited help, for punishment itself does nothing to redress the physical, relational, moral and material dimensions of the harm inflicted. Whatever other social good the punitive justice system may achieve (and there is some), it is not empowered to heal. Something more powerful than punishment is needed to loosen 'the bond of victimisation' that binds victims and offenders together in the pain and shame of the criminal event and to bring repair.

\section{Restoring what?}

But what, precisely, is this damage that needs repair? What does restorative justice actually restore? This question may be answered in various ways. Some stress the role of material and financial restitution, the making good of the physical losses caused by the crime. Others emphasize the rehabilitation of offenders, their reintegration into law-abiding society. Others speak of the restoration of the victim's dignity, or mana, or sense of security and peace of mind. Some deny that anything is restored, objecting to any suggestion that the clock can be turned back and the past retrieved. There are some losses that can never be made good, such as the life of a murder victim, or the independence of someone disabled by a drunk driver, or the innocence of a child subjected to sexual abuse; and even lesser offences change things for ever. Others object to the implication that justice is being restored, since justice may never have existed in the first place. As I was frequently asked in Taiwan, how can you have restorative justice in an unjust society? What is needed is not a return to some imaginary justice of the past, but a transformative justice that works for social change.

Clearly, then, the phrase itself is ambiguous. But, to my mind, what is fundamentally in need of repair are the relationships violated by the wrong. This includes the relationship between victim and offender, and also the relationships each has to others in their wider social group which have also been affected. These relationships are not being restored to what they were before; they are being restored to 'rightness', to what they ought to be like in the circumstances. Even if the parties never knew each other personally prior to the crime, their co-participation in the criminal event has created a relationship between them, an unhealthy and destructive relationship that needs to be restored to a rightful condition. The same applies to all the other layers of relations that constitute us as social creatures, since we are relational beings all the way down.

Because interpersonal relationships are reciprocal and storied realities, one of the most effective ways to initiate change is by means of direct or mediated encounter between the parties: a meeting where the story of the damage done through the 
collision of their lives in the wrongful event is told as truthfully and fully and compassionately as possible, and where all those directly affected together decide what is needed to write a new chapter in the saga, so that the relationship can be restored to rightness. That is the heart of restorative justice.

\section{Restoring trust}

Before finishing, I want to return to Ross London's work which I mentioned at the outset, both because it serves to sharpen the focus even further on what restorative justice restores, and because it does so in a way that has direct bearing on that second big trend I noted in restorative justice internationally, the growing interest of governments in the approach.

In his somewhat protracted analysis, London is often quite critical of the rhetoric surrounding restorative justice in the literature. He especially dislikes the common claim that it is an entirely 'new paradigm' for doing justice, fundamentally incommensurate with the values of the prevailing system (pp.26272, cf. pp.13-22). To assert, as proponents often do, that restorative justice is both a new paradigm and the recovery of ancient or indigenous ways of achieving justice is self-contradictory. It can't be both. It is also self-defeating. Exaggerated claims of novelty will only serve to keep the practice on the margins of the mainstream justice system, as an exotic diversionary strategy for petty offending rather than as a comprehensive model for systemic change.

Yet, while denying that it is a wholly new paradigm, London still thinks there is something genuinely new about restorative justice. Its greatest innovation is not its creation of a new set of criminal justice practices, such as victim-offender mediation or family group conferences. What is 'wholly original and crucial' is its goal of repairing the harm of crime. 'Whereas the traditional goals of the criminal justice system are to deter, censure, incapacitate, and rehabilitate offenders, restorative justice poses an entirely new and original goal: repairing the harm of crime' (p.24).

What, then, London asks, is the harm that needs to be repaired? I have made a case for seeing it as the damage done to the relationships that bind us together in society and comprise our essential humanity. But London finds that explanation too generic and abstract. It doesn't help us, for example, to distinguish between the kind of relational damage caused by crime and the kind caused by non-criminal wrongs, such as jealousy, insensitivity, gossiping and so on. It is better, he thinks, to see relational damage as the result of the harm, not as the harm itself. The real harm associated with the commission of crime is the loss of trust. It is the betrayal of the most basic expectations we have of our fellow human beings - which is, put simply, to live by the negative form of the Golden Rule, 'not to do unto others as you would not simply presumes the minimal expectation that he or she will play by the same rules, so that society can accommodate their presence without fear or force. Of course, even this minimal expectation still presupposes relationship. Mutual trust is meaningless outside of a relational context. Even if the parties to a crime had no previous personal relationship, in so far as their common membership of society necessitates mutual trust they were still in relationship.

That said, I am persuaded that there is much to be gained from focusing specifically on the relational component of trust. It helps to explain, for example, the power of the central elements of restorative justice dialogue, such as story-telling, accountability, emotional

\section{All members of society, ... have a legitimate interest in seeing crime prosecuted and punished, as a necessary precondition for the existence of social}

trust.

have them do unto you'. If we are to live together in security and peace we need to trust that everyone will abide by this rule, that they will not to try to overcome our will through fear or force or fraud. Crime confounds this expectation. Crime shows that we can no longer trust the person who has broken the rules and threatened our safety. The wrongdoer has proven themself to be 'untrustworthy', an outsider to the law-abiding community.

What is most needed, then, in the wake of crime is to regain trust in the offender. Not a perfect trust, but a basic trust that he or she will respect the rights, feelings and values of others and regulate his or her behaviour without the need of external coercion. Offenders must prove their readiness to be readmitted to the moral community by showing their trustworthiness again.

The virtue of focusing on the restoration of trust rather than the restoration of right relations, London suggests, is that it does not presume the existence of a previous or ongoing personal relationship with the offender; it honesty, apology, restitution, community engagement and commitment to moral change. These are precisely the things needed to heal breaches of trust and restore relationships to rightness.

Even more telling is the way trust functions as the common property of both personal and social relationships. The trust of personal relationships depends on having subjective knowledge of the individual to be trusted. The trust of social relationships, on the other hand, requires an objective confidence that the wider social order will operate predictably and fairly according to agreed-upon standards, and that even strangers will hold themselves accountable to the Golden Rule.

One critical prerequisite for the existence of social trust is confidence that the state will act to redress the breaches of trust that occur through criminal offending and enforce the standards of behaviour encoded in the law. If the state fails to do so it denies its own legitimacy. All members of society, therefore, have a legitimate interest in seeing crime 
prosecuted and punished, as a necessary precondition for the existence of social trust. This is one of government's primary responsibilities, one that some restorative justice advocates are too quick to decry. Rather than disparaging the punitive system root and branch, they should affirm the state's obligation to sustain the reservoirs of social and personal trust in society, and commend restorative justice as a promising new tool for doing so more effectively.

\section{Towards a restorative justice system}

London's chief concern is to find a way of straddling the divide between the informal itself is 'an extraordinarily poor way of restoring trust in either an offender or in society' (p.105, emphasis added). It is only when punishment is accompanied by such 'indicia of trust' as acceptance of blame, empathy, remorse, apology and restitution that evidence exists for rebuilding personal trust..$^{5}$ This is where restorative justice has a powerful role to play. An offender's willingness to engage in a dialogue with his victims, and with the community he has betrayed, provides a unique setting for honest explanation, acceptance of moral responsibility, manifestations of empathy, voicing of apology, and a commitment to future

\section{Of course, efforts to integrate restorative priorities and practices into the mainstream justice system, and into the social order at large, are not without risk. Peril exists on all sides.}

justice of victim-offender encounter and the formal justice of the public system. The key to unifying these two domains, he believes, is to understand both as ways of serving the larger goal of restoring trust. The criminal justice system exists to uphold the necessary conditions for social trust. This requires it to employ all the procedural safeguards enshrined in the mainstream retributive system, such as due process, just deserts, equal access, predictability, proportionality, consistency and so on. These principles help to satisfy society's need for certainty and security. But within these objective parameters judges still need to address the problem of personal trust attaching to the individual offender. In sentencing, judges should be guided, London suggests, by three simple but penetrating questions: Why don't I trust this person to re-enter society right now? What must he or she do, and over what period of time, to demonstrate their trustworthiness? And what evidence do I have to help me answer these questions? (p.55).

While the lawful imposition of punishment may be necessary to sustain social trust, he writes, punishment by change, all of which are the seeds of renewed 'trustability'.

Crucially, everything an offender does in such a setting to regain trust also benefits his victims. As well as meeting their needs for information, reassurance and vindication, it helps them to restore their trust 'that the world is inhabited by people who are much like ourselves: people with a conscience, with empathy; people who play by the same rules as we do and, if they break those rules, understand the wrong they have committed and accept the agreed-upon consequences of their wrongdoing' (p.105).

\section{Conclusion}

London makes an intriguing case for the integration of restorative justice processes into the criminal justice system in a way that both supports and transforms mainstream practice. It supports the mainstream system by endorsing its necessary function of upholding the rule of law and protecting the innocent, and it transforms it by proposing a new way of understanding the overriding goal of sentencing and punishment. 'Guided by the goal of restoring trust in the offender and in society', London writes, 'we can devise a criminal justice system that promotes genuine healing, forgiveness, and reintegration' (p.89).

The key to this integration is the recognition that the principal harm of crime is the loss of trust. This loss is only so devastating a problem because we are irreducibly social creatures, who only ever exist in an intricate network of relationships. The malice of intentional wrongdoing serves to violate the trust on which these relationships depend, and when that happens it is the core business of restorative justice practice - encounter, truth-telling, accountability, confession, contrition and restitution - that has unrivalled power to begin to heal the breach.

Of course, efforts to integrate restorative priorities and practices into the mainstream justice system, and into the social order at large, are not without risk. Peril exists on all sides. Restorative justice is imperilled by the possibility of institutional capture and control, and by the dilution of its distinctive values. The justice system is in peril of having its adherence to procedural fairness and equality of outcome compromised by idiosyncratic and potentially anarchic restorative justice processes. Both threats are real, though they may often be exaggerated. ${ }^{6}$ It is my hope that, in this wonderful country of ours, ever conscious of the perils entailed we may continue to work together - as practitioners, policy makers, politicians and ordinary citizens - to move the vision of restorative justice, and all that it promises, from the margins of our consciousness to the mainstream of how we live together in society, in faith, hope and charity.

\footnotetext{
1 This article is the edited text of Professor Marshall's inaugural lecture, delivered at Victoria University on 25 March 2014.

2 On restorative justice as a social movement, see Umbreit and Peterson Armour (2010), pp.1-33.

3 As Umbreit and Armour (2010, p.318) comment, 'the identification of a program as "restorative" can be confusing because others cannot determine if the word refers to the movement's values and principles, its aims and outcomes, its specific processes, its programs, or combinations thereof'.

4 Johnstone (2012, p.156) observes that, 'increasing numbers of people are seeking not only to reform "external" organisations and social practices in line with the ideas of restorative justice, but to practice principles such as these in their own lives and to encourage others to do so. Nor, for many, is this an optional extra. Rather, there is a fairly widespread view among campaigners for restorative justice that it would be contradictory and self-defeating to seek to "restorativise" the societal response to crime while behaving non-restoratively in the workplace and in our everyday lives. Trying to transform ... society's response to crime is now
} 
just one concern ... of a social movement which aims to propagate a new way of seeing the world and living in it'. 5 'By voluntarily submitting to a deserved punishment, the offender indicates that he respects the rules of the game of reciprocal altruism; by his apology, he expresses his renunciation of the contempt he has shown for the rights of the victim and for all those who play by the rules; by his agreement to make restitution, he expresses his agreement not to profit from his freeloading; by his voluntary agreement to submit to rehabilitation, he expresses his desire for commitment to change; and, finally, by the totality of these actions and expressions, he indicates his desire to return to the good graces of the moral community' (London, 2011, p.83).

6 'Commentators have asked whether restorative justice practices can co-exist alongside formal criminal justice approaches and given the widespread acceptance of restorative justice, evident in the expansion of restorative justice to encompass adult offenders and more serious offences, this question seems to have been answered. Restorative justice practices provide an important supplement to the sanctions placed on criminal behavior by the traditional criminal justice system' (Joudo Larson, 2014 p.35).

\section{References}

Acorn, A. (2004) Compulsory Compassion: a critique of restorative justice, Vancouver: UBC Press

Braithwaite, J. (1989) Crime, Shame and Reintegration, Cambridge: Cambridge University Press

Johnstone, G. (2012) Restorative Justice: ideas, values, debates, 2nd edn, London: Routledge

Joudo Larsen, J. (2014) Restorative Justice in the Australian Criminal Justice System, AIC research and public policy series, 127, Canberra: Australian Institute of Criminology

London, R. (2011) Crime, Punishment, and Restorative Justice: from the margins to the mainstream, Boulder, Col. and London: First Forum Press

Lynch, N. (2012) 'Playing catch-up? Recent reform of New Zealand's youth justice system', Criminology and Criminal Justice, 12, pp.507-26

MacRae, A. and H. Zehr (2004) The Little Book of Family Group Conferences New Zealand Style, Intercourse, Pa: Good Books

Marshall, C.D. (2012) Compassionate Justice: an interdisciplinary dialogue with two gospel parables on law, crime, and restorative justice, Eugene, Oreg: Cascade Books
Shaw, George Bernard (1961). The Crime of Imprisonment New York, Citadel Press.

Sherman, L.W. and H. Strang (2007) Restorative Justice: the evidence, London: Smith Institute

Strang, H., L.W. Sherman, E. Mayo-Wilson, D. Woods and B. Ariel (2013) Restorative Justice Conferencing (RJC) Using Face-to Face Meetings of Offenders and Victims: effects on offender recidivism and victim satisfaction. a systematic review, Oslo: Campbell Systematic Reviews, 2013:12

Umbreit, M. and M. Peterson Armour (eds) (2010) Restorative Justice Dialogue: an essential guide for research and practice, New York: Springer Publishing

Zehr, H. (1990) Changing Lenses: a new focus for crime and justice, Scottdale, Pa: Herald Press

Zehr, H. (2002) The Little Book of Restorative Justice, Intercourse, Pa: Good Books

\section{The New Electoral Politics in New Zealand}

\section{Edited by Jack Vowles}

Around the world there was unusual interest in New Zealand's electoral politics during the 1990s, because of the country's adoption of the Mixed Member Proportional (MMP) electoral system. Since then, international interest has lapsed. Yet at the 2011 election, at a concurrent referendum, New Zealanders voted to retain the MMP system. Among other inquiries, this book asks the question: why?

Since the 2005 election, there are signs that New Zealand has adapted to MMP and become accustomed to a 'new electoral politics'. Voting choices have become less volatile between elections and during campaigns. The two main parties, National and Labour, have retained their dominance of the votes, but in their respective terms of government they have been obliged to share power with other parties. At the next election in 2014, as in 2011, the choice appears to be between a National government, with perhaps one or two minor parties in support, or a Labour and Green Party coalition. Yet other parties could still complicate the picture: in particular, Winston Peters' New Zealand First.

Looking back to the 2011 election and before, this book lays out the current state of the play in New Zealand's electoral politics. Despite its reservations about MMP, the National Party has done very well under that system, particularly since 2005 , with a vote share and polling that made it well within reach of a single-party majority in 2014. For these reasons, apparently, National appears unwilling to change the MMP system in ways recommended by an Independent Review. Various chapters in this book explore these questions, as well as others, including voter turnout decline, attitudes to welfare reform, women's representation, changes in Maori politics, and the growing importance of immigration in New Zealand politics and society.

Jack Vowles is Professor of Comparative Politics at Victoria University of Wellington. Other contributors to the book are Peter Aimer (formerly at the University of Auckland), Gerald Cotterell, Jennifer Curtin, Louise Humpage, Aimee Matiu, Raymond Miller, Ann Sullivan, and Martin Von Randow (all currently at the University of Auckland), Charles Crothers (AUT University), Jeffrey A. Karp (Australian National University) and Thomas Lundberg (University of Glasgow).
An Institute for Governance and Policy Studies Publication edited by Jack Vowles Publication Date: May 2014. Format: A5 Paperback, pp 276

ISBN 978-0-475-12414-2. Price: $\$ 39.95$ (including P\&P within New Zealand)

Place your order by phone or email. Preference is for payment via credit card, but invoices can be issued on request

Institute for Governance and Policy Studies, Victoria University of Wellington

Email igps@vuw.ac.nz Telephone +6444636588

P0 Box 600, Wellington, New Zealand
Edited by Jack Vowles

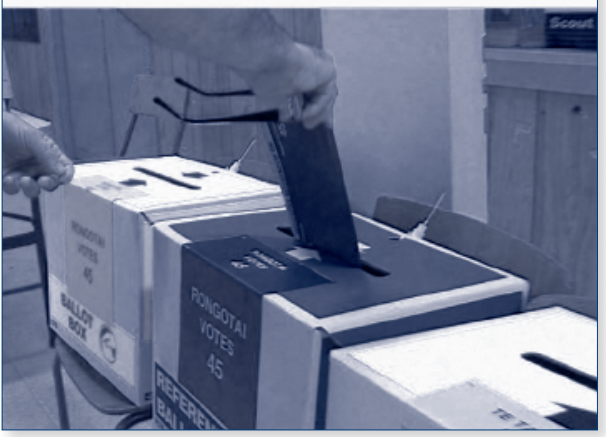

VICTORIA and Policy Studies 